\title{
Between Innovation and Tradition: Code-Switching in the Transmission of the Commentary to the Félire Óengusso
}

\author{
Nike Stam*
}

This article presents a case study that explores the issue of code-switching in medieval text transmission with initial data mined in a three-year project run at the Dublin Institute for Advanced Studies. The case study is based on a bilingual corpus of glosses and notes in Irish and Latin that accompanies the ninth-century Martyrology of Oengus. This collection of material is referred to as the Commentary to the Félire Oengusso and is found in ten manuscripts. This provides an excellent opportunity to compare different versions of a bilingual text in order to analyse the way in which different scribes dealt with the bilingual material that they copied. In my analysis, a twofold approach to the material will be adopted: first, from the perspective of linguistics, I examine whether the grammatical characteristics of a code-switch influence its transmission. For this, I use Pieter Muysken's typology of code-mixing (2000) to distinguish between complex and simple code-switches. Secondly, from the perspective of palaeography, I examine whether highly abbreviated words that could be interpreted as either Latin or Irish (visual diamorphs) may cause so-called »triggered « code-switches in transmission. The aim of the comparison is to provide a window on scribal practice in bilingual texts.

Keywords: bilingualism; code-switching; Ireland; Old Irish; Latin; typology; transmission; palaeography; visual diamorphs; martyrology; Oengus Mac Óengobann; glosses; commentary

\section{Introduction}

Pais luceri deochain.

diar fiadat ba sercach.

sruith nola næb sochlach

felix flan $n$ fin $n$ fechtnach.

(14 January, UCD A7, fol. 6rb, 1. 21-25)
The passion of Deacon Glycerius

To our Lord he was loving

Felix the elder of Nola, holy, famous

Fland, fair (and) happy. ${ }^{1}$

* Correspondence details: Nike Stam, Dublin Institute of Advanced Studies, School of Celtic Studies, 10 Burlington Road, Do4 C932, Dublin 4, Ireland; since June 2021: Utrecht University, Trans 10, 3512 JK Utrecht, the Netherlands; email: n.stam@uu.nl.

1 Stokes, Félire Óngusso Céli Dé, 35; Stokes, On the Calendar of Oengus, xxvii. 
This Irish quatrain was written at the beginning of the ninth century by Óengus Mac Óengobann, the bishop of Tallaght ( $\dagger$ c. 830$).^{2}$ It is part of a martyrology that enumerates several saints in a single vernacular quatrain for each day of the year. ${ }^{3}$ As Óengus chose to write just one quatrain for each day and did so in the strict Irish metre rinnard, ${ }^{4}$ there was little room for him to elaborate on the saints themselves - for example, on their place of origin, their miracles, their martyrdom. Over time, therefore, scholia and glosses accumulated in the margins around the poem to provide additional information. This body of material is usually referred to as the Commentary to the Félire Oengusso (CFÓ). ${ }^{5}$ The Flann mentioned in the quatrain cited above, for instance, receives the following gloss:

\section{\#1401 FLANN FINN FECHTNACH nescio ubi est hic flan $n$ sed alii dicunt conad $h$ flan $n$ febla comharba patraig. ${ }^{6}$ (UCD A7, fol. 6rb, 1. 24-25)}

FLANN, FAIR (AND) HAPPY I do not know where this Flann is, but others say that it is Flann Febla, the successor of Patrick.

This gloss, like many others surrounding this text, is bilingual and contains both Latin (up to alii dicunt »others say«) and Irish (the name Flann, and the clause from conadh »that it is" onwards).

2 For a discussion of the linguistic dating of the Martyrology, see Stokes, On the Calendar of Oengus, 1, 6-11; Strachan, Deponent verb in Irish, 110-112; Stokes, Félire Oengusso Céli Dé, xxviii-xxxviiii; Thurneysen, Abfassung Des Félire von Oengus, 6-8; Breatnach, Poets and poetry; Dumville, Problems of dating; and Ó Riain, Feastdays, 80-118. The current consensus is a date around 800 or somewhat later.

3 The poem itself also contains some Latin words and names; see Hennig, Studies in the Latin Texts, 64 for a list.

4 Each quatrain in this metre has four lines, each of which contains six syllables. The final word of each line should end in two syllables and could make a rhyme or consonance with another line; see Murphy, Early Irish Metrics, 64.

5 Stokes variously referred to the material as "the glosses « and »the notes «: Stokes, On the Calendar of Oengus, 11822; Stokes, Félire Óengusso Céli Dé, xlvii. Ó Riain, Feastdays, 173-204, however, refers to it as the Commentary, which is the name commonly used in bibliographies; see, for example, the relevant entry in the bibliography CODECS, accessed on 14 May 2021: www.vanhamel.nl/codecs/Commentary_on_F\%C3\%A9lire_\%C3\%93engusso.

6 The transcriptions from the manuscript University College Dublin, Franciscan A7 (F) are my own, as are the translations of the material, unless otherwise stated. In these transcriptions, expanded abbreviations are indicated by italics. Word separation and capital letters are kept as in the manuscript. Each gloss is introduced by a reference to its lemma in the form of a hashtag, followed by the day and the month at which it occurs. For this gloss, that is \#1401c for the third lemma (c) of the 14th of January. These lemmata are used as part of the XML-encoding of the transcription, which will be made available online at a later stage of the project. The numerical reference to the lemma is followed by the lemma itself, indicated by small caps.

Manuscript images of $\mathrm{F}$ are available online through the Irish Script On Screen project, hosted at the Dublin Institute for Advanced Studies (www.isos.dias.ie/english/index.html, accessed on 3 April 2019). The line numbers in F are counted using both the large script of the martyrology and the smaller script of the interlinear notes and the notes following each quatrain. Even though the ruling is visible throughout the page, I have only counted the lines that have been written on. 
Such use of two languages in a single "communicative event", whether spoken or written, is a phenomenon referred to as code-switching. ${ }^{7}$ While this term was originally developed for the analysis of spoken bilingualism, it has proven to be a useful tool for the analysis of historical sources. ${ }^{8}$ Its success lies in the fact that there are many similarities between code-switching in speech and in writing with regard to grammatical constraints as well as with regard to its various communicative functions. Combining these linguistic models with well-tried historical methods has highlighted the linguistic complexity of historical communities and their written records. Furthermore, using these linguistic models has revealed information that is otherwise lacking in our sources, such as information on societal norms; ${ }^{9}$ vice versa, the historical material has complemented modern theories in adding a diachronic dimension which has the ability to prove or disprove their proposed universality.

\section{Historical Documents as Bilingual Discourse}

Of course, this is not to say that studying historical documents with methodologies developed for spoken utterances is always smooth sailing. There are many stormy waters that will need to be navigated in the near future, not least the differences between language production in speech and in (historical) writing. ${ }^{10}$ Another matter that needs to be addressed is that of text transmission. Often, the historical texts under investigation are not contemporaneous with the manuscripts that contain them and may have a long and complex history, during which their language, lay-out, and content may have been altered at any stage of copying. Therefore, the bilingualism of historical texts, glosses, sentences, and clauses may, in fact, be the result of editorial decisions or scribal corruptions rather than the result of language production. ${ }^{11}$ It is all the more important to remain aware of what may happen to bilingual material when it is copied in the case of the extremely flexible genre of glosses and commentaries: the lay-out of glosses (often interlinear or in the margins of a text) invited additions, deletions or

7 Schendl and Wright, Code-Switching in Early English, 23.

8 Odstrčilík, Multilingual medieval sermons, 142-144; Schendl, Multilingual texts as a reflection, 149-150; Ter Horst, Typology and spectrum, 235. See also Ter Horst, Irish-Latin Leabhar Breac, and Stam, Typology of Code-switching, in which Pieter Muysken's Typology of Code-Mixing is used (see also below). For an overview of studies up to 2017 that use concepts developed for the spoken language and apply them to historical sources, see Stam, Typology of Code-switching, 49-94. This overview includes areas like medieval German, English and Irish. More recently, see Ó Flaithearta and Nooij, Code-Switching in Medieval Ireland, and Pahta et al., Multilingual Practices, as well as the various contributions to Medieval Worlds 12 (2020) by Odstrčilík, Schendl, Bériou, Delcorno, Negoi, and Ter Horst respectively.

9 Stam, Typology of Code-switching, 373-379; Ter Horst, Typology and spectrum.

10 Sebba, Language Mixing and Code-Switching; Stam, Typology of Code-switching, 49-65; Negoi, Bilingual strategies, 212. Sebba in particular has proposed a new approach to written code-switching that includes semiotics, literacy, and visuality.

11 An interesting example of this is discussed in Ter Horst, Typology and spectrum, 245-251, with regard to IrishLatin homilies that have been copied into various manuscripts as well as in Bériou, Orality in its written traces. 
new combinations. Furthermore, glosses carried less authority than the main text and may therefore have been more likely to be changed by the scribes. ${ }^{12}$ That some code-switches in bilingual glosses may, in fact, be the result of additions, deletions, or translations by later scribes was also stressed by Jacopo Bisagni in the case of Irish-Latin code-switching in the eighth-century Würzburg glosses, ${ }^{13}$ by Pádraic Moran regarding the glosses in the St Gall Priscian, ${ }^{14}$ and by Alderik Blom regarding the glosses in the Southampton Psalter. ${ }^{15}$

A complicated transmission, however, makes it all the more interesting to study these texts from the perspective of code-switching, since it helps us to focus on a new layer within the mechanics of written bilingual language production: the layer of the scribes and copyists who worked on bilingual texts after their composition. The scribes copying these bilingual texts would have needed to activate both their languages (»bilingual mode») in order to successfully combine two monolingual glosses into one bilingual gloss. ${ }^{16}$ An example of this intricate combination of two languages may even be seen between lemma and gloss:

Bisagni, Amra Coluim Chille, 14-17; Charles-Edwards, Manuscript transmission, 119-120.

Bisagni, Prolegomena, 23-30. These glosses have Latin, monolingual cognates in another manuscript (Cambridge, Trinity College, MS B.10.5, hereafter B), which allowed Bisagni to make a comparison between the bilingual corpus in the Würzburg manuscript (Wb) and the monolingual corpus in B. From this comparison, it becomes clear that some Irish glosses that occur in $\mathrm{Wb}$ are translations or adaptations of Latin glosses, as in this example:

B f 21v: i. praedicata est crux Christi uobis quasi eam oculis uideritis (»i.e., Christ's cross has been preached to you as though ye had seen it with [your] eyes«).

Wb 19b6: .i. ro pridchad dúib céssad Crist amal ad cethe [...] (»i.e., Christ's Passion has been preached to you as though ye had seen [it]«). (Bisagni, Prolegomena, 27)

Although there are some differences between the two (oculis, for example, is left untranslated and crux Christi is translated as céssad Crist »the passion of Christ«), it is clear that both glosses are related. In other examples, glosses that were originally monolingually Latin, were used to create bilingual glosses:

B f 8r: .i. a deo

Wb 13a24: .i. a deo i tindnacul raith (»i.e., by God in bestowal of grace«) (Bisagni, Prolegomena, 28)

The gloss in $\mathrm{Wb}$ has the appearance of a bilingual gloss containing an inter-phrasal switch between two prepositional phrases, but the evidence from B suggests that the two phrases might originally have been separate units that appear side by side in this manuscript, perhaps due to scribal considerations of lay-out or compilation.

14 Moran, Language interaction, 16: »[...] the respective layers [of glossing, NS] become visually inseparable in the course of copying and recopying. These glosses are therefore just as likely to be the result of textual accretion rather than spontaneous bilingualism.»

15 Blom, Glossing the Psalms, 68: „Some of the Irish SUB1 glosses are immediately followed by a Latin phrase in the same hand, often introduced by <.i. $>$ or $\langle\nmid>$ : [...] ad-selbem $>$ I testify< [...] is followed by: .i. quae sequuntur hic 'which follow here<, a phrase which also occurs in the Vatican Commentary, suggesting that this composite gloss was not originally bilingual. « See also p. 69: „Even so, it appears that genuinely bilingual glosses do not occur. In fact, most of the bilingual phrases can be shown to have been compiled from separate sources. This does not imply, however, that these glosses were not read as a single utterance, but the compilatory nature of the gloss resulted in a paratactic structure (uel [...] uel) in which the two languages are not integrated in terms of syntax."

16 The term »language activation« is used here as defined by François Grosjean: »the state of activation of the bilingual's languages and language processing mechanisms at a given point in time« (Grosjean, Bilingual and monolingual language modes). In bilinguals, this looks as follows: »[b]ilinguals will be in a bilingual mode when interacting with other bilinguals who share their languages and with whom they feel comfortable bringing in the other language. In this case, both languages are active, but one language is slightly less active as it is not the main language of communication« (Grosjean, Bilingual and monolingual language modes, 2). 
Ml. $66^{\mathrm{b}} 4$ datorem deligit Deus "God favours a giver«

i. adidnopair fessin dudia o degnimaib

i.e. who offers himself to God with good works. ${ }^{17}$

The Old Irish gloss here consists of a relative clause, which is borne out by the use of the infixed pronoun id $n$ - in the verb ad-opair, which is only used in relative clauses. ${ }^{18}$ Furthermore, the form of the infixed pronoun is in agreement with its antecedent (datorem, accusative of dator "a giver") in number and gender (masculine singular). This makes the Irish relative clause directly dependent on a Latin antecedent. To be able to create this Irish relative clause, a scribe would have needed to activate his knowledge of both Latin and Irish in order to properly link it to its Latin antecedent. While this case cannot be classified as a code-switch, since the two languages are not contained in a single discourse (see above), it does demonstrate the close ties between the two languages even across the divide of lemma and gloss. A second reason for including this material is that the readers who were dealing with the end result of such scribal activity would also have had to process any bilingual material as code-switches. ${ }^{19}$

Returning to the text we started with - the Commentary to the Félire Oengusso - it is likely that this text, too, has undergone a complex process of textual accretion and deletion in the course of its history: the text occurs in a total of ten manuscripts in varying degrees of completeness, each individual copy containing a version that is ever so slightly (or ever so greatly) different from its relatives. However, each individual copy is bilingual. The following table shows the 10 manuscripts and their sigla, as well as the material that they contain: ${ }^{20}$

17 Taken from the Milan Glosses database created by David Stifter and Aaron Griffith, see www.univie.ac.at/indogermanistik/milan_glosses/, last accessed on 3 April 2019.

18 For the use of different classes of infixed pronouns in Old Irish, see Thurneysen, Grammar of Old-Irish, 255-270.

19 That Grosjean's concepts of language activation and bilingual mode apply to both oral and written bilingualism is clear from Grosjean, Studying bilinguals, 137: "Everything that has been said about speakers also pertains to listeners or readers. For example, and whatever the base language, if listeners determine (consciously or not), or find out as they go along, that what they are listening to can contain elements from the other language, they will put themselves partly in a bilingual mode, that is, activate both their languages (with the base language being more strongly activated). This is also true of readers, whether they are reading a continuous text or looking at individual lexical items interspersed with items from the other language. Simply knowing that there is a possibility that elements from the other language will be presented (in an experiment, for example) will move the bilingual away from the monolingual endpoint of the continuum.« See also Dijkstra et al., Interlingual homograph recognition.

20 Stam, Typology of Code-switching, 102-104. The tenth manuscript, manuscript NLI G169 (C2) is a direct copy of C made in 1806 and is of no independent value. 


\begin{tabular}{|c|c|c|c|}
\hline Sigla & Shelf mark & Date & Lacunae \\
\hline $\mathrm{R} 1$ & $\begin{array}{l}\text { Oxford, Bodleian, } \\
\text { Rawl. B505 }\end{array}$ & $\begin{array}{l}\text { early } 15^{\text {th }} \\
\text { century }\end{array}$ & $\begin{array}{l}\text { One gathering; lacks preface, prologue and } \\
\text { epilogue. }{ }^{21}\end{array}$ \\
\hline $\mathrm{Lb}$ & $\begin{array}{l}\text { Dublin, RIA } 23 \text { P } 16 \\
\text { (Leabhar Breac) }\end{array}$ & $1408-1411$ & \\
\hline $\mathrm{L}$ & $\begin{array}{l}\text { Oxford, Bodleian, } \\
\text { Laud } 610\end{array}$ & $\begin{array}{l}\text { early } 15^{\text {th }} \\
\text { century }\end{array}$ & \\
\hline$P$ & Dublin, RIA 23 P 3 & $1467-1470$ & $\begin{array}{l}\text { Lacks preface, prologue, May, September } \\
\text { and December due to loss of leaves. }\end{array}$ \\
\hline $\mathrm{F}$ & Dublin, UCD A7 & 1490 & \\
\hline $\mathrm{R} 2$ & $\begin{array}{l}\text { Oxford, Bodleian, } \\
\text { Rawl. B512 }\end{array}$ & 1500 & $\begin{array}{l}\text { Lacks the body of the Félire, part of the } \\
\text { prologue and the notes to May, June, July, } \\
\text { most likely due to loss of leaves. }{ }^{22}\end{array}$ \\
\hline C & Dublin, NLI G1O ${ }^{23}$ & 16th century & $\begin{array}{l}\text { Lacks mid-March to mid-November, most } \\
\text { likely due to lack of leaves. }{ }^{24}\end{array}$ \\
\hline B & $\begin{array}{l}\text { Brussels, } \\
\text { BR 5100-4 }\end{array}$ & 1630 & \\
\hline B2 & $\begin{array}{l}\text { Brussels, } \\
\text { BR 5057-5059 }\end{array}$ & 17th century & $\begin{array}{l}\text { Extract of poetry from the notes to March, } \\
\text { April, September and October as well as } \\
\text { some additional material. }{ }^{25}\end{array}$ \\
\hline
\end{tabular}

No extant manuscript is contemporary with the composition of the Martyrology or the Commentary. All ten manuscripts date from the fifteenth century onwards and are thus at least six centuries removed from the ninth-century origin of the Martyrology. ${ }^{26}$ While this lack of contemporaneous manuscripts makes it more difficult to trace the scribal processes of translation, compilation, and deletion in the Commentary from the beginning of the tradition, it does allow for a comparison across the different versions of the existing manuscripts in order to analyse the way in which later scribes transmitted bilingual material.

$21 \mathrm{R} 1$ is a composite manuscript, of which $C F O$ makes up the second part as a separate gathering of five bifolia; see Ó Cuív, Catalogue of Irish Manuscripts, 210. It is unclear whether the lack of the preface, prologue and epilogue is due to the loss of separate gatherings or whether the scribe had no interest in these elements of the text.

22 Ó Cuív, Catalogue of Irish Manuscripts, 242.

23 In Stokes, Félire Oengusso Céli Dé, ix-xii referred to as the Cheltenham Manuscript.

24 Ní Shéaghdha, Catalogue of Irish Manuscripts, 62.

25 The indexation and editing of the material in this manuscript is part of the current project.

26 This is, unfortunately, very common in medieval Irish studies. For more information on the loss of Irish manuscripts from the period 900-1200, see Russell, Irish language, 989-991, 993: "Irish prose texts have been written in manuscripts since at least the eighth century. However, owing to both factors of historical discontinuity and the local environmental conditions (such as wet climate and acid soil), very few manuscripts in Ireland itself survive from the Old Irish period (c. 600-900), and none of these is a collection of Irish-language literary prose fiction. Therefore, we rely on surviving later copies." The dating of these texts to earlier periods is generally done through an analysis of the linguistic strata of the language (Russell, Irish language, 990). Further suggested causes for the loss of medieval Irish manuscripts are given in Ó Corráin, Ireland's medieval manuscripts, and Sharpe, Books from Ireland. 


\section{Bilingual Textual Variation as a Window on Scribal Practice}

Bilingual variation in different versions of the same text can provide insights into the ways in which scribes dealt with bilingual material. As is to be expected, the glosses in $C F O$ show variation in the deletion and translation of Latin but also in the length, form, and accurateness of each individual Latin code-switch. Due to the lack of manuscripts predating the fifteenth century, however, the role of the scribe can only be analysed in manuscripts that appear to be closely related to each other in terms of their transmission. Only then can we plausibly exclude the activities of copyists working in the period(s) for which we have no direct witnesses. Determining which manuscripts are closely related is, unfortunately, impeded by the fact that not all copies of the Commentary have been edited as yet. As a result, only two tentative attempts have been made to create a stemma of the transmission of the Félire and the Commentary. One of these was created by an anonymous participant of the 1911 summer school, held at the School of Irish Learning in Dublin. It was never published, but it was discovered by Pádraig Ó Riain while working on his Feastdays of the Saints. ${ }^{27}$ Due to its mysterious origins, we know very little about this stemma; we do not know, for example, whether it was based on the metrical Martyrology, on the Commentary text, or on both. ${ }^{28}$

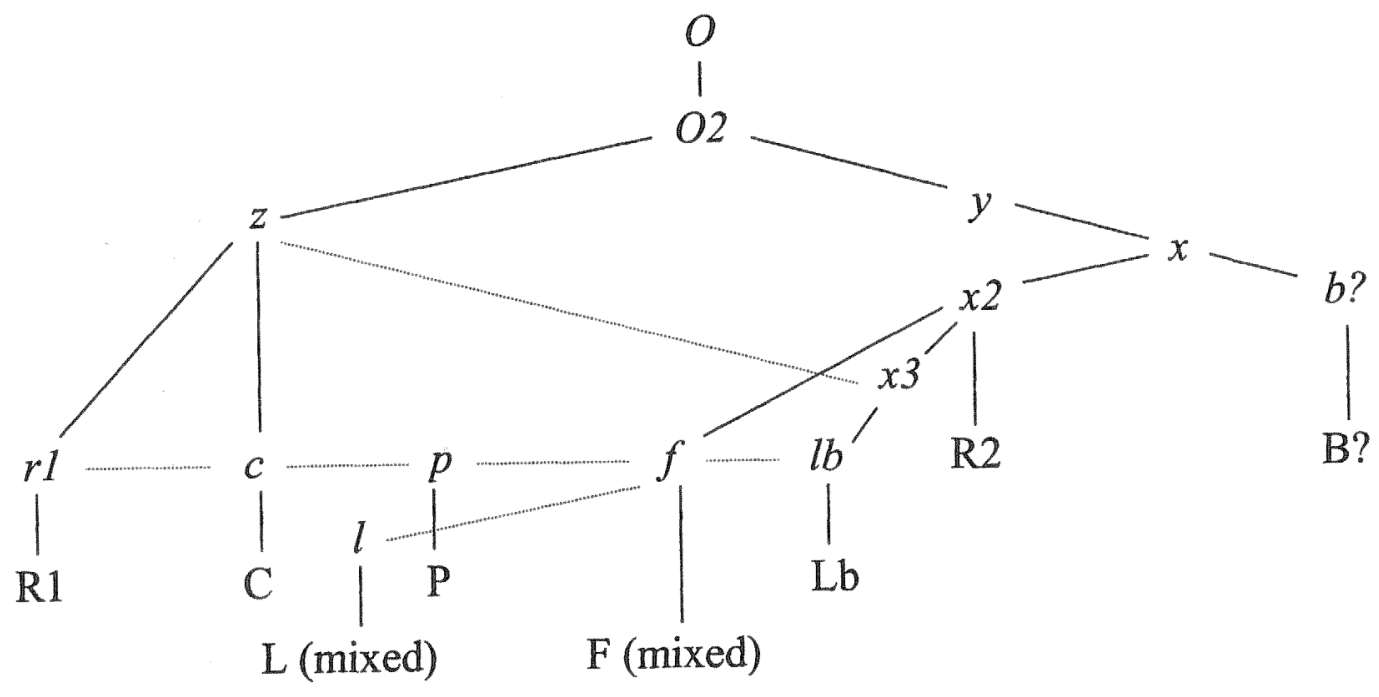

Fig. 1: The 1911 stemma of (C)FÓ, Ó Riain, Feastdays, 177.

In the same book, Ó Riain himself also created a working stemma, based on four excerpts from the Commentary:

28 For the shelf numbers of the sigla used above, see the list above. In the second stemma, the sigla L1 is used by Ó Riain, Feastdays, 182, to indicate that L shows influence from two sources, one from the $z$-branch (L) and one in the $y$-branch (L1). 


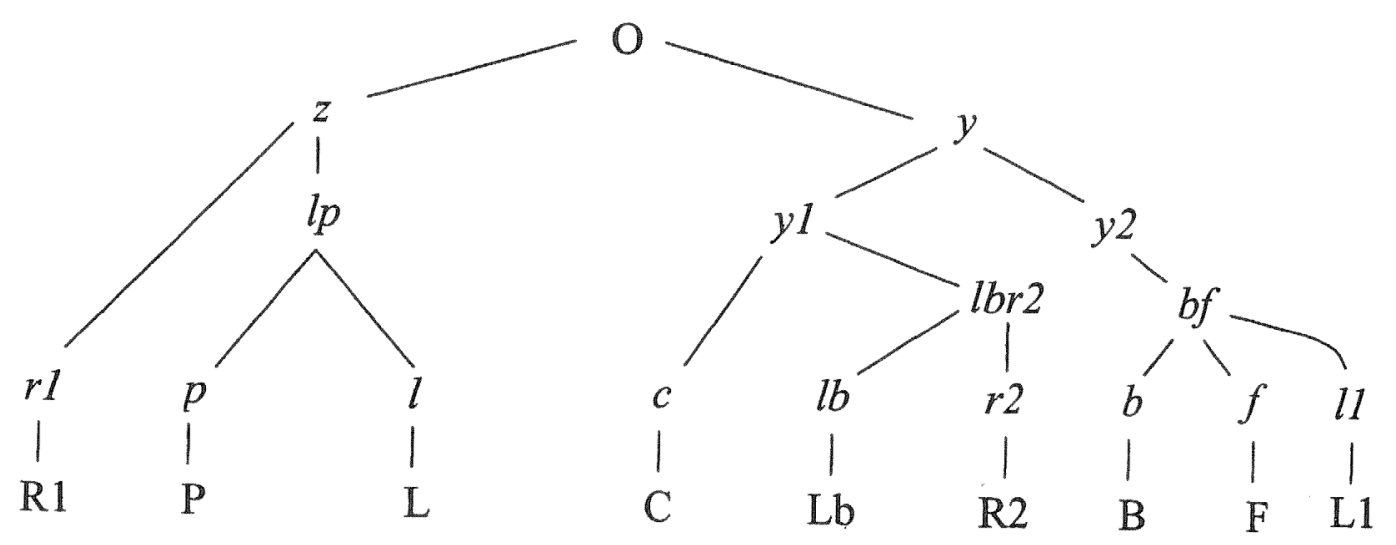

Fig. 2: Ó Riain's stemma for CFÓ, Ó Riain, Feastdays, 182.

Both stemmata are similar in that they show that no manuscript is directly derived from another extant one. Yet, they diverge greatly in terms of the details of these relations, with the 1911 stemma displaying much more cross influence between the different manuscripts than the 2006 stemma. Since some question may be posed concerning the 2006 stemma, ${ }^{29} \mathrm{I}$ have based the choice of two manuscripts for this case study on the 1911 stemma by selecting the manuscripts University College Dublin A7 (F), and Royal Irish Academy 23 P 16 (Lb). ${ }^{30}$ Both copies are complete and they are closely related in the stemma through the common node $\mathrm{x} 2$ as well as through the relationship between the nodes $f$ and $l b$ (Figure 1). ${ }^{31}$

29 See Stam, Typology of Code-switching, 107-125 for a discussion of this. Without a full edition of all extant versions of the Commentary, or an extensive discussion of the material, it is impossible at this stage to verify either of the two stemmata.

30 The manuscript Oxford, Bodleian Library, Laud 610 will be included in the comparison at a later stage of the project. It is a composite manuscript, the oldest segment of which contains the Félire Oengusso. This segment is thought to have been written between 1410 and 1452 for James Butler (fols. 59-72 and fols. 123-46). After his death, it came into the possession of Edmund Butler, James' nephew, who combined his uncle's manuscript with material that had been written for himself (Ó Cuív, Catalogue of Irish Manuscripts, 62). While the scribe of the earliest segment is unknown, the scribe of the later segment identifies himself as Seaan Buidhi ó Cléirig or Yellow Sean Ó Cleirigh (Stokes, Félire Oengusso Céli Dé, xv). The manuscript has seen its share of adventure, as it was used as a ransom for Edmund when he was held prisoner by Thomas Fitzgerald, the earl of Desmond (Ó Cuív, Catalogue of Irish Manuscripts, 67).

31 I am aware that it might not be useful in the case of texts such as glosses and commentaries to speak of a stemma; considering the complex life of glosses, it might be more useful to aim at distinguishing different layers. However, the existing stemma is here used to provide a starting point for the comparison. 
Manuscript $\mathrm{F}$ is part of what is called The Franciscan Archive, a collection of manuscripts that is now housed in University College Dublin but which had previously been kept at Franciscan institutions in Louvain, Rome, and Dublin. ${ }^{32}$ Its colophon identifies the scribe as Ruaidhri hUa Luinin, who wrote the book for Cathal Mac Maghnusa Meguidhir ( $\nmid 1498) .{ }^{33}$ This Cathal is praised highly in the Annals of Ulster (a. 1498.8) as someone "who was full of grace and of knowledge in every science, both law and divinity, physic and philosophy, and knowledge of Gaidhelic also to the time of his decease " and someone who had occupied various functions within the church: "canon choral in Ard-Macha and in the bishopric of Clochar and dean over Loch-Erne and parson in Inis-cain of Loch-Erne and who was in the deanery of Loch-Erne as vicar of the bishops for 15 years before his decease «. ${ }^{34}$

The manuscript RIA 23 P 16, or Leabhar Breac, "the Speckled Book", may be dated somewhat earlier, to the period 1408-1411. We owe this precise dating to the scribe of the manuscript, Murchad Ó Cuindlis, who notes the death of Cobhthach Ó Madaghain in 1411 and the fact that he has been travelling for over three years to collect the texts for his manuscripts, thus giving us a terminus ante and post quem of 1408-1411. Murchad is known to have been a pupil of the Lecan historian Gilla Ísa Mac Fir Bisig Murchad, and his hand was identified in this manuscript by Ó Concheanainn. ${ }^{35}$ It is unclear for whom exactly it was written, but it has been suggested that it was for a religious community. ${ }^{36}$

\section{A Threefold Approach to Bilingual Scribal Variation}

In the project, bilingual variation in these manuscripts is approached from a number of angles: first, from the perspective of philology, variation in code-switching across manuscripts may depend on the intended audience and on the attitude of the scribes. It is possible that scribes writing for a religious community will have had a greater interest in the Latin and bilingual glosses than scribes writing for a secular lord. Additionally, their training in Latin might allow them to retain Latin code-switches more accurately or might even encourage them to add new material in Latin.

32 See Dillon et al., Catalogue of Irish Manuscripts, 14-16. The Franciscan collection is now housed in University College Dublin and has been made available through Irish Script on Screen (accessed on 3 April 2019: www.isos.dias.ie).

33 Stokes, Félire Óengusso Céli Dé, xii-xiii, and O’Donovan et al., Martyrology of Donegal, xiv state that Cathal Mac Maghnusa died in 1470, but it is unclear where they sourced this information, as the Annals of Ulster record his death under 1498 (see celt.ucc.ie/published/T100001C/, a. 1498.8, accessed on 3 April 2019). For 1470, the Annals do mention a raid on Cathal Mac Maghnusa: "a. 1470.17 The sons of Donchadh, son of Aedh Mag Uidhir and the sons of Cormac, son of the same Aedh, made a foray on Cathal Mac Maghnusa junior in Rinn-Airigh«, celt.ucc.ie/published/T100001C/texto93.html, accessed on 3 April 2019

341498.8 Scél mór i n-Erinn uile isin bliadhain-si: .i. so sís. Mac Maghnusa Mheg Uidhir do ég in bliadhain-si: .i. Cathal Og, mac Cathail, mic Cathail, mic Gilla Padraig, mic Matha \& araile; neoch bui ina bhiatach for Seanadh \& ina chanánach coradh i n-Ard Macha \& i n-espucoidecht Clochair \& ina dheganach for Loch Eirne \& ina persun a n-Inís Cain Locha h-Erne \& do buí a n-degántacht Locha h-Erne ina fer-inaid espuic fri u. m-bliadhna x. ria n-a eitsecht. Ind leacc loghmur imorro \& in gem gloine \& in retla sholusta \& cisti taiscedha ind ecnai \& craebh cnuasaigh na Canoine \& topur na desherci \& na cennsa \& na h-ailgine \& in coluim ar gloine cridhe \& in turtuir ar endca \& in nech d'ar' buidhighi dama \& deoraidh \& deiblein bochta Erenn \& in nech \& buí lan do. Taken from the "very unsatisfactory edition " of Hennessy and Mac Carthy, Annals of Ulster, digitised on the CELT initiative: for the Irish text, see celt.ucc.ie/published/G100001C.html, and for the translation see celt.ucc.ie/published/T100001C.html.

35 Ó Concheanainn, Scribe of the Leabhar Breac, 67.

36 Ó Concheanainn, Scribe of the Leabhar Breac, 65. See Ter Horst, Irish-Latin Leabhar Breac for a recent, in-depth analysis of the manuscript, its scribes, and its quire structure. 
Secondly, from a linguistic perspective, variation may be dependent on the chronological development of the linguistic status of Irish vis-à-vis Latin in medieval Ireland, particularly within commentary texts. This genre is likely to have displayed a chronological development akin to that of the Annals, i.e. from a monolingually Latin form to a monolingually Irish form, with a mixed, bilingual Irish-Latin form in the period in between. ${ }^{37}$ This intermediate bilingual stage might show both quantitative and qualitative changes in the appearance of Latin: the quality of Latin code-switching will change from complex to simple, while the overall quantity of Latin will decrease in favour of Irish. To define "complex" and "simple« code-switching, Pieter Muysken's Typology of Code-Mixing is a useful starting point. ${ }^{38}$ According to Muysken's Typology, complex forms of code-switching include alternation (long phrases, clauses, and sentences) and congruent lexicalisation (syntactically complex elements like conjunct particles). Simpler forms of code-switching include insertion, which is the insertion of small elements like single nouns, and conventionalised code-switching, which is code-switching in set expressions and idioms. ${ }^{39}$ The degree to which any of the quantitative or qualitative developments appear in different versions of the same text might provide insight into the relative chronologies of bilingual texts.

Thirdly, from a palaeographical perspective, so-called visual diamorphs may trigger unconscious code-switching by writers and scribes into either language, as was suggested in Stam and Ter Horst and Stam. ${ }^{40}$ Visual diamorphs are elements in texts that are linguistically ambiguous, either because they are highly abbreviated or because they are words that have the same form in both languages involved. ${ }^{41}$ Their influence may be examined by determining whether there is more variation in the transmission of code-switching around these elements.

\section{A Linguistic Case Study of CFÓ}

While the project as a whole will entail the analysis of bilingual glosses in the three different manuscripts, the present case study will present the results of an initial examination of the first six months of the Martyrology in two manuscripts discussed above (F and Lb). Due to the small size of the sample, my focus here will only be on the linguistic aspects of the bilingual glosses, and not on the overall material philology: the complete data set is necessary to determine the attitudes of scribes and patrons towards the bilingualism in the commentary.

37 The development in the annals is described in Dumville, Latin and Irish.

38 Muysken, Typology of Code-Mixing; Stam, Typology of Code-switching.

39 Pieter Muysken has used the term conventionalised code-switching to denote code-switches that "have gained acceptance within a particular speech community « (Muysken, Typology of Code-Mixing, 71), but that have not been integrated to such a degree that they might be considered borrowings. In Stam, Typology of Code-switching, 298299, I have used a minimum of five occurrences in the same source to include a code-switch as a conventionalised code-switch, but this is in need of refinement through a comparison across sources.

40 Stam, Typology of Code-switching, 328-361; Ter Horst and Stam, Visual Diamorphs, 223-242. Following linguistic research on triggering (Clyne, Dynamics; Myslín and Levy, Code-Switching and predictability), triggering is a form of code-switching in which proper names, unintegrated loans, and bilingual homophones induce an unconscious change of language.

41 For example, the abbreviations 7 »and «, $\nmid$ »or«, $\mathrm{q}$ »because«, $\overline{\mathrm{s}}$ »but«, and .i. »that is«, function as Latin in a Latin context and as Irish in an Irish context. When they occur in bilingual material at switch points, it is undesirable to expand them in the transcription into either language, as their ambiguity is an integral part of the bilingual nature of the text. The diamorphic nature of such elements was originally noted by Wright, On variation, and Voigts, Character of the Carecter. 
The linguistic make-up of the commentary for the months January till June is as follows: these months contain a total of 857 glosses, 210 of which are bilingual (25\%), ${ }^{42} 129$ are Latin (15\%), and 509 are Irish (59\%). Some of the glosses (9, or $1 \%$ ) are ambiguous, because the words they contain could belong to both Latin and Irish, like the word martir "martyr « in its nominative case. In the 210 bilingual glosses, a total of 394 code-switches occur.

The total number of code-switches has been divided into several categories: ${ }^{43}$ adjectival phrases (AP), adverbial phrases (BP), determiner phrases (DP), noun phrases (NP), prepositional phrases (PP), verb phrases (VP), function words (FW) ${ }^{44}$ coordinate clauses (CC), main clauses (MC), subordinate clauses (SC, with a separate category for relative clauses RC), and long switches that stretch across several phrases or clauses (LongAlt):

\begin{tabular}{|l|l|l|l|}
\hline & Number of CS in F & Number also in Lb & Percentage also in Lb \\
\hline AP & 5 & 4 & $80 \%$ \\
\hline BP & 29 & 12 & $41 \%$ \\
\hline DP & 8 & 8 & $100 \%$ \\
\hline NP & 140 & 108 & $77 \%$ \\
\hline PP & 27 & 18 & $67 \%$ \\
\hline VP & 8 & 8 & $100 \%$ \\
\hline FW & 1 & 0 & $0 \%$ \\
\hline CC & 46 & 34 & $74 \%$ \\
\hline SC & 31 & 23 & $74 \%$ \\
\hline RC & 17 & 11 & $65 \%$ \\
\hline MC & 21 & 14 & $67 \%$ \\
\hline LongAlt & 61 & 46 & $75 \%$ \\
\hline Total & 394 & 286 & \\
\hline
\end{tabular}

42 This percentage is slightly higher than the percentage of bilingual glosses in the manuscript Bodleian Library, Rawlinson B505, in which $18.7 \%$ of the glosses were bilingual (Stam, Typology of Code-switching, 173). In the same manuscript, $57.2 \%$ of the glosses were monolingually Irish, $23.7 \%$ of the glosses were monolingually Latin, and $0.4 \%$ of the glosses were ambiguous.

43 In counting code-switches, I follow the methodology set out in Stam, Typology of Code-switching, 162-171. This means that the gloss is the basic unit of analysis and is assigned a matrix language. Any code-switches in the glosses are then flagged using Muysken's list of features for insertion, alternation, and congruent lexicalisation. In the case of alternation and congruent lexicalisation, however, there is no over-arching matrix language, which means that each sequentially switched element will be counted as an individual code-switch. For example, if a gloss starts on an Irish main clause, followed by a Latin subordinate clause, which is in turn followed by an Irish coordinate clause, both the Latin subordinate clause and he Irish coordinate clause are counted as code-switches.

44 As defined in Brown and Miller, Cambridge Dictionary of Linguistics: »In contrast with a lexical word, a grammatical word does not denote an entity - a thing, a being, an event, an abstract idea and so on - but carries information about the grammar of clauses«, s.v. Grammatical Word (Function Word). 
While the first column shows the number of code-switches across the different categories in manuscript $\mathrm{F}$, the second column shows how many of these also appear as a code-switch in $\mathrm{Lb}$, which is conveyed as a percentage in the third column. Noticeable from these figures is that, generally, there is a very high chance that a code-switch in $\mathrm{F}$ will also appear as a codeswitch in Lb: except for the single switched function word, only the category of adverbial phrases scores below $65 \% .{ }^{45}$

These results need to be further refined: we need to look more closely at the reasons why some of the code-switches that occur in F do not occur in Lb. There may be several reasons for the non-retention of a switch; for example, the gloss that contains the switch in F may not exist at all in Lb (percentage missing). Alternatively, the bilingual gloss may appear both in $\mathrm{F}$ and $\mathrm{Lb}$, but may have a different form in $\mathrm{Lb}$ (percentage changed). The following table shows how many of the bilingual glosses in F do not appear at all in Lb.

\begin{tabular}{|l|l|l|l|l|l|}
\hline & $\begin{array}{l}\text { Number of } \\
\text { CS in F }\end{array}$ & $\begin{array}{l}\text { Number of } \\
\text { CS not in Lb }\end{array}$ & $\begin{array}{l}\text { Glosses mis- } \\
\text { sing }\end{array}$ & $\begin{array}{l}\text { Percentage } \\
\text { missing }\end{array}$ & $\begin{array}{l}\text { Percentage } \\
\text { changed }\end{array}$ \\
\hline AP & 5 & 1 & 1 & $100 \%$ & o \\
\hline BP & 29 & 17 & 7 & $42 \%$ & $58 \%$ \\
\hline DP & 8 & 0 & 0 & 0 & 0 \\
\hline NP & 140 & 32 & 19 & $59 \%$ & $41 \%$ \\
\hline PP & 27 & 9 & 6 & $67 \%$ & $33 \%$ \\
\hline VP & 8 & 0 & 0 & 0 & 0 \\
\hline FW & 1 & 1 & 1 & $100 \%$ & 0 \\
\hline CC & 46 & 12 & 7 & $58 \%$ & $42 \%$ \\
\hline SC & 31 & 8 & 3 & $37 \%$ & $63 \%$ \\
\hline RC & 17 & 6 & 6 & $100 \%$ & 0 \\
\hline MC & 21 & 8 & 2 & $25 \%$ & $75 \%$ \\
\hline LongAlt & 61 & 7 & 6 & $86 \%$ & $14 \%$ \\
\hline Total & 394 & & & & \\
\hline
\end{tabular}

Since these glosses do not appear in Lb in their entirety, they can provide no information on how their scribe dealt with copying a bilingual gloss itself. ${ }^{46}$ I shall therefore focus on the glosses that occur in both manuscripts but that do not contain the same code-switch. This means that adjectival phrases, determiner phrases, verb phrases, function words, and relative clauses are excluded, since they have either not been changed in transmission (DP, $\mathrm{VP}$ ) or since the gloss that contains them in F is entirely absent in Lb (AP, FW, RC). Included are adverbial phrases, prepositional phrases, main clauses, subordinate clauses, coordinate clauses and long alternations across clauses or phrases.

45 The switched function word is the Latin preposition post, which in its abbreviated form may have acted as a visual diamorph: \#0906c .i. Baithin mac brenaind .maic. ferghusa ab ia post colum .cille. (...) »i.e. Báithín mac Brenainn maic Fergusa, abbot of Iona after Colum Cille (...)«. This example will be discussed in more detail in a forthcoming publication that will compare the code-switches in $\mathrm{F}$ and $\mathrm{Lb}$ with code-switches in $\mathrm{L}$.

46 Except, of course, for the fact that a scribe may have had a tendency to delete or add bilingual glosses. To examine this, the consistency with which the monolingual glosses appear across the different manuscripts should be compared with the results for the bilingual glosses. This, however, lies outside the scope of the present article. 


\section{Adverbial Phrases}

There are ten glosses that contain a switched adverbial phrase in F but not in Lb. The causes for this seem to be threefold: translation, deletion, and abbreviation. There are two glosses in which translation seems to have caused a code-switch to disappear (assuming that the code-switch is the lectio difficilior): \#0101d and \#2106b. In the first example, the gloss explains the phrase from the martyrology stating that Christ "submitted to the law « or, in other words, underwent circumcision. In F, the Latin sic »thus" appears as the Irish sís »downwards « in Lb, where the order of the elements in the gloss is different as well:

\#0101d LUID FOREACHT ARD ERAIL Luid $h$ forecht ard erail 7 rł [...] .i. íncroicen $n$ fas bis acen $n$ anboill fherrdha sic $ł$ neraín .i. furail .i. inforimad $h$ bec noteasctha an $n \nmid$ iserail uasal tesctha peccáigh ochach crist do dul forecht nimdibhe ł urain .i. ímarcraidh do techt forecht nimdibe. (fol. 5ra, 1. 20-25)

[Christ] SUbmitTed to THE LAW, High THE REQUiRement! He submitted to the law, high the requirement etc, [...] i.e. the empty skin that is wont to be the head of the masculine member thus, or [read] nerain, i.e. furail »abundance", i.e. the small excess that was wont to be cut there, or Christ submitting to the law of circumcision is a noble injunction of cutting sin from everyone, or read urain, i.e. a surplus submitting to the law of circumcision.

Lb: [...] .i. incroicend remaniusa riacach .i. réim náiniusa. ł romain .i. remshamud. infás bís acind inbaill fherrdai sis. no nerain .i. furail .i. in forimad bec nothesta and. (p. 78b, 1. 16-18) ${ }^{47}$

"[...] the empty thing that is wont to be the head of the masculine member downwards $[\ldots] \ll^{48}$

While sís might alternatively have arisen as a misreading of sic, the end result is still a correct Irish clause in which a code-switch is translated in the broadest sense: the general meaning of the gloss remains unchanged - a meaning that is conveyed with a code-switch in F but without one in Lb.

A clearer case of translation may be found in $\# 2106 \mathrm{~b}$, again of the word sic, represented in Lb by its Irish equivalent amlaid sin:

\#2106b CORMAC BA CAIN CLEIRECH .i. ualiathan indermaig ímidhe IS fris adbert colum .cille. Airis arse sunn indirmuig. Niairisium icein $¥$ cofarcbusa ní dotthaisib occum. Doro cucat ní dib ol colum .cille. Dolam ind olcormac. Sínis colum .cille. alam Scothais cormac alutaing de. ISgoirt domai[r]lis achormaic olcolum .cille. Cidfil an $n$ olse acht coín dotithi ind issed ón rocomailled. ISe didiu incormac sin rotriall tar muir indeagaid. colum .cille. coneracht ínmhuir fris conarleig tairis he onchinniud gorocomailltea briathar .coluim.cille. sic (fol. 23rb, 1. 13-24)

47 RIA 23 P 16 or Lb is also available online at Irish Script On Screen (accessed on 3 April 2019: www.isos.dias.ie). The line numbers have been counted according to the lines of the larger script of the Martyrology itself from p. 79 onwards. The glosses are generally located around these lines either in the interlinear space (IL), in the bottom margin (BM), right margin (RM), left margin (LM), or top margin (TM). The first page of the Commentary (p. 78) is different in that it has no marginal or interlinear material but collects the glosses and notes in a column as running text. In this case, the line numbers reflect individual lines, regardless of the size of the script.

48 The meaning of this gloss is slightly different from that in F, as it uses fás as a substantivised adjective »empty thing «. 
CORMAC WAS A FAIR CLERIC i.e. [he was] of the Uí Liathain in Durrow in Meath. It is to him that Colum Cille said: "Stay here, " he says, "in Durrow." »I will not stay unless you leave some of your relics with me." "You will get some of them, « says Colum Cille. "[Put] your hand onto it, " says Cormac. Colum Cille stretched out his hand. Cormac cuts his little finger off him. "You have attacked me bitterly, o Cormac! « says Colum Cille. "Nevertheless, " says he, "wolves will eat you for this." And that was fulfilled. He is that Cormac who travelled across the sea after Colum Cille, and the sea rose against him, so that she did not allow him to pass her, because of the determination that Colum Cille's word should be fulfilled in that way. (Adapted from Stokes, Félire Óngusso Céli Dé, 156-159).

Lb: [...] onchindiud corocomailltea briathar coluim .cille. amlaid sin (p. 90, 1. 2-8 RM)

There are five glosses that lack the switched adverb altogether in Lb (\#0804b; \#2001a; \#0503c; \#0704b; \#1706d). In two of these, either the whole clause is missing (\#2001a, fol. 7ra, 1. 17; Lb p. 80, l. 13 RM), or just the adverb itself (prius \#0906d, fol. 21va, l. 6). ${ }^{49}$ For the other three examples, the way in which the lemma or synonym is introduced in the gloss in each manuscript creates the code-switch or the lack thereof:

\# 0503C CARTHACH RIGHDHA RUAMACH Carrtach uero. i. mac fingin mac noi mac cellain mac tailgin $n$ mac firb aquo .h. fhirb (fol. 11vb, l. 27-28)

CARTHACH, ROYAL, CITY-POSSESSING Cartach, then, i.e. the son of Fingen, son of Noe, son of Cellán, son of Tailgenn, son of Firb from whom [are] the Uí Fhirb.

Lb: .i. Carthach mac find maic noei maic cellain maic tailcind maic firb a quo .hui. firb. (p. 83, 1. 3 RM)

In the gloss above, the lemma from the Martyrology is Carthach, which is introduced as "Carthach then, that is [...]«. In Lb, the gloss simply starts on the explanatory .i., followed by the name Carthach. ${ }^{50}$

The abbreviated adverb uero features as a point of divergence in glosses \#2001d and \#0102b as well. In each of these glosses, $\mathrm{F}$ seems to prefer the abbreviated uero as an adverb meaning »then «, while Lb prefers to use the abbreviations for Irish immorro or didiu, which have roughly the same meaning. ${ }^{51}$ In both cases, the words are part of a narrative gloss. Here follows the example from January:

49 Note, however, that in the gloss in F, prius has been inserted over the word baiste as a correction of the text.

50 Other examples: \#0704c BA GERAIT CRIST CAINDE Bagerait críst .uero. [...] (fol. 15ra, l. 16); lemma not introduced in Lb. \#0804b A TEMPAIL .i. eclesie didiu »a church therefore«, (fol. 15rb, l.17); Lb .i. eclesia »a church« (p. 85, l. 15 IL).

51 Note, however, that variation exists, since F collects another gloss on Carthach, in which the lemma is introduced by dano (Carrthach dano dalta ciarain saigri he [...] "Carthach, then, he was a student of Ciarán of Saiger « fol. 11vb, 1. 29). This reintroduction of the lemma may point to the fact that the scribe considered this to be a new gloss on the lemma and, perhaps, that this new gloss was taken from a different source. 
\#2001d Sabbaist 7 Oenu Oenu .i. oenghus mac ui laighse dolaichis laighin docuaidh 7 daghilla maille fris forfecht (GAP)l inam $h$ sa corigh connacht. Condechaid iarum coport innsi clothrann ictriall tarloch rí siar. Ecmaing dano ciaran isin indsi tunc 7asbert. Tabair amaigh in toglach airbidhfer corath de he jbidhé gebhus mocomarbussa domeis. (GAP)naghar oenghus amuigh. Ciaairet doshet olciaran. corigh connacht aringilla. Nachferr lat dochur corigh nime 7talman arciaran. Mase achoir dano arangilla ISe .uero. arciaran. Tescthar afholt 7ailter frisineclais 7 gabais comarbus ciarain iarsin ut ciaran profetauit. (fol. $7 \mathrm{ra}, 1.38$ - 7rb, l. 4)

Sebastian and Óenu Oenu, i.e. Óengus son of the Uí Laigse of Leix of Leinster. He went, along with two servants, on a journey to enter military service to a king of Connacht, and he came to the port of Inis Clothrann, passing over Loch Rib westwards. Now Ciaran happened to be on the island then and he said »bring the young hero in [to the island], for he is a man with God's grace, and it is he who will take my coarbship after me." Óengus is then taken in. "Where are you going?" said Ciaran. »To the king of Connacht, « said the youth. »Were it not better for you to put yourself to the king of heaven and earth?" said Ciaran. "If it be proper, " said the youth, »It is in truth." says Ciaran. His hair is cut, and he is reared at the church and he took Ciaran's coarbship afterwards, as Ciaran prophesied. (Adapted from Stokes, On the Calendar of Oengus, xxxviii)

\section{Lb: [...] issed immorro olciaran. [...] (p. 80, 1. 24 RM)}

Considering the fact that the abbreviation for uero is also used in monolingual Irish texts for the Irish words immorro and didiu, this particular abbreviation might be included into the list of visual diamorphs. Additionally, discourse-shaping elements like these might easily be changed in the process of copying and could therefore reveal the individual preferences of scribes. ${ }^{52}$

Another abbreviation that may be added to the list of visual diamorphs is the abbreviation for quam "than", used in comparisons. The following gloss shows that an Irish comparison, "it is fitter than", is constructed with the abbreviation for Latin quam, while in Lb this is constructed with the Irish iná:

\#1101a A HEIGHIPT NA ${ }^{53}$ SUBAE Cidfodera conadsollomuin tuidecht críst ahegipt 7 nach sollamain adul in $n$ ti .nihansae. arægipt isinun $n$ 7tenebre בiscora suba dotiactain neich eisibsidhe iarruin quam dodul inntibh. (fol. 6ra, 1. 38)

Out of Egypt, FUll of GLADNEss Why is it that Christ's coming out of Egypt is a festival and his going into it is not a festival? Easy to say, since »Egypt«is the same as »darkness", and fitter is happiness at one's coming out of it than at going into it according to the mystical meaning.

Lb: Cid fodera conid sollamain tidecht crist ahegipt 7 nach sollamain adul innte. ni hansae. árisinand egiptus $\mathrm{I}$ tenebre .i. dorcadae $\mathrm{I}$ iscoru suba dothiachtain neich esti ina dul inntib. (p. 79, 1. 31 RM)

52 Another example is \#0102b BRIGHIT BAN BALC NUALANN [...] Maith ale maccleirig tall olbrigit. ínfil anmcara lat Ata .uero. arinmaccleirech. Gaib eim aecnairc olbrigit (fol. 8va, l. 30-31). BRIGIT THE FAIR, STRONG, PRAISEWORTHY [...] "Well, O young cleric there, " said Brigit, »do you have a soulfriend? « "I have indeed, « said the cleric. "Let us sing his requiem, « said Brigit. [...] (Adapted from Stokes, On the Calendar of Oengus, xlvi)

Lb: [...] Maith ale ameicclérig thall olbrigit infil anmchara lat. ata immurro olinclerech. gaibem aecnairc olbrigit. [...] (p. $82 \mathrm{BM}$ ).

53 Under $n a$ is written lān as a correction (fol. 6r., 1. 31). 
It must be noted, again, that the abbreviated quam may be found in monolingual Irish texts for Irish iná, indaas "than", which shows that this abbreviation functions in both Irish and Latin linguistic contexts and thus acts as a visual diamorph. ${ }^{54}$ If the abbreviations for uero and quam are included in the list of visual diamorphs, then they cannot be counted as code-switches in an otherwise monolingual Irish context.

\section{Prepositional Phrases}

When examining the category of prepositional phrases, we find different causes for the lack of switching in Lb: for the three glosses that occur in each of the two manuscripts in a different form, the mobility of the material on the page and the deletion of elements seem to play a stronger role, while there are no examples of translations or ambiguous abbreviations. ${ }^{55}$ Gloss \#1005a is a good example of the type of code-switching that is created by the mobility of the material on the page, as discussed by Bisagni. The single phrase glóir in caelo »voices in heaven « in F forms two separate glosses in Lb:

\#1005a Hi SITHLAITH IND ALLTAIR I MBI TOIRM CECH TEMPAIL

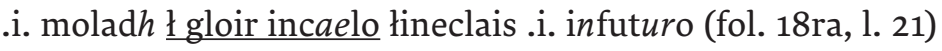

INTO THE OTHER WORLD'S REALM OF PEACE, WHEREIN IS EVERY TEMPLE'S NOISE

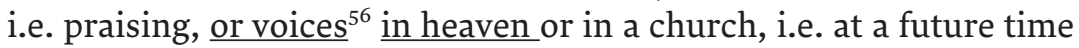

Lb: .i. molad łgloir hic .i. incaelo ł ineclais .i. infuturo (p. 87, l. 19 IL)

i.e. praising or voices here, i.e. in heaven or in a church, i.e. at a future time

54 The following gloss from F shows that two parts of a gloss on Joseph deal with the word for »than« in the same comparison differently:

\#1903e IOSEPH AINM IS UAISLIU .i. do aite issu dorad $h$ frihiosep $h$ quam ioseph $\nmid$ isuaisliu aiti issu dorad $h$ ris inaioseph. JOSEPH, NAME THAT IS NOBLER i.e. [it is nobler] for him to call Joseph "Jesu's tutor « than "Joseph«, or it is nobler to call him "Jesu's tutor" than »Joseph«. (fol. 13rb, l. 33-35)

Lb: .i. do aite isu dorad frihiosep .i. quam iosep $ł$ is uaisle aite ihesu dorad ris ina iosep (p. 84, 1. 6 IL)

Note that the gloss itself collects two different readings: one with the abbreviation for quam and one with the Irish reading ina. In Lb, however, the Latin quam is separated from the syntax of the Irish clause by .i., "that is".

55 With the concept "mobility of material«, I intend to describe the flexibility that glosses and other marginal material display in transmission, i.e. that they are very likely to be combined, split up, and recombined as well as very likely to appear at different places on a page or in a different order in each manuscript witness. On the complexity and flexibility of glosses in transmission, see Bisagni, Amrae Coluimb Chille, 17 and the discussion in Stam, Typology of Code-switching, 106-109.

56 Alternatively, glóir may denote »glory«; see eDIL s.v. 1 glóir or dil.ie/26118. 
A prepositional phrase that simply does not occur in Lb may be found in $\mathrm{F}$ for \#1805b, which contains a Latin phrase referring to a source. ${ }^{57}$

\#1805b MOMOEDHOC MOR MOEINECH .i. momoedoc fedha duin ínosraighi i. momoedoc mac midhgna maic meite maic nindeda maic naxair maic crimtain maic eachach maic ængusa maic cathair mair ín eadem genelogia (fol. 19ra, l. 20-25)

My Maedóc great and treasurous i.e. My Máedoc of Fid Dúin in Ossory, i.e. My Máedóc son of Midgnae son of Nindid, son of Nastar, son of Crimthann, son of Eochaid, son of Óengus, son of Crimthann, son of Cathaír Mór [is] in the same genealogy.

Lb: i. momóedoc fheda duin inosraigib .i. momoedoc mac midgnai maic meti maic nindedai maic nazair maic crimthain maic echach maic oengusa maic crimthainn maic cathair mair 7 colam mac nindeda maic nazair maic crimthain maic echach maic oengusa maic crimthannain maic cathair máir (p. 88, l. 3 IL - RM)

\section{Main Clauses}

Main clauses show yet another pattern: all six glosses that contain code-switches in F may be shown to be separate glosses in Lb. Here, then, the mobility of the glosses during their transmission plays an important role. The quatrain for the ninth of June, for example, is accompanied by a wealth of glossing material, since it is the feast day of one of Ireland's best-known Saints: Colum Cille. The following excerpt from a longer gloss explains how he got his name:

\#0906c Colum Cille cainnlech [...] Cuimine didiu 7 míncloth 7 sinech. tri sethra coluim .cille. Colum pro simplicitate eius dictus est [...]. ${ }^{58}$ (fol. 21va, l. 9-10)

Colum Cille the lustrous [...] Cuimine, then, and Míncloth and Sinech [are] the three sisters of Colum Cille. Colum was so called because of his simplicity. [...] (Adapted from Stokes 1880, On the Calendar of Oengus, xcix)

Lb: Cuimine didiu 7 mínchloth 7 sinech. tri seathra choluim chille. (p. 89, l. 14 RM) Colum pro simplicitate eius dictus est. [...] (p. 89 BM)

In $\mathrm{Lb}$, the material is presented separately as the Latin main clause is the start of a separate account in the lower margin of the manuscript page..$^{59}$

57 Similarly: \#0805b AR CRÍsT COTA RUICSET [...] ł roimarchuirsedar aneire arcríst ininitio ætatis. (fol. 17vb, l. 38-39) For Christ THEY HAVE BRoUght THEMSELVES [...] or they carried about their burden for the sake of Christ from a young age.; Lb: ł roimchuirset aneri arcrist (p. 87, l. 16 IL)

58 The Latin sentence in $\mathrm{F}$ begins on a new line and has been given a capital letter. This might indicate that it is consciously set apart as different material.

59 Other examples: \#2204b; \#2404a; \#2904d; \#2405d (2x). The material will be published online at a later stage in the project. Until then, the material will be available upon request. 


\section{Subordinate Clauses}

The five subordinate clauses are also not retained as a code-switch in Lb due to the mobility of the material. It is important to note that all code-switches in this category are of a conventionalised or formulaic nature: generally, they are forms of the Latin verbs dicere or canere used to introduce poetry. In \#0602a, the phrase ut poeta cecinit is used in F to link material that is presented separately in Lb:

\#0602a EsPoC Mel MIND RIgHe Darerca dano incoiced siur dophadráig mathair espuic mel ut poeta .cecinit. Lupait 7 tigris ten $n$ feib rorimes isrichell. [...] (fol. 9ra, 1. 29-34)

Bishop Mel, A DiAdem of The Kingdom Darerca, then, one of Patrick's five sisters, [was] Bishop Mel's mother, as the poet sang: Lupait and Tigris the severe, as I have recounted, and Richell, [...]. (Adapted from Stokes, Félire Óengusso Céli Dé, 68-69)

Lb: [...] Darerca siur patraic máthair espuic moel. 7 ise dorat grada forbrigit 7 bagrada espuic iatside 7 isiat bis for acomorba diahessi (p. 81, l. 11 IL RM) Lupait 7 tigris $^{\text {proprium }}$ tend feib doruirmess is ricell [...] (p. $81 \mathrm{BM}$ )

In glosses \#2102a, \#2203d, \#1106d, and \#3006d, extra material, present in $\mathrm{F}$ but not in $\mathrm{Lb}$, is introduced by means of the phrases ut dixit, ut dicitur and ut est. This confirms that these phrases are used as a "textual glue", allowing the linking of existing materials in the commentary or the addition of new material to it. Gloss \#2203d, for example, explains the phrase "over the rampart of the sea". While a similar gloss exists in Lb, the gloss in F is longer because of an added ut dicitur which is intended to introduce an illustration of the word doë »rampart«:

\#2203d BALC LESS LER TAR DOA Tardoa 7rł [...] $ł$ ismor íntshoillsi failbe tardoe. .i. tarcladh $\nmid$ darcrich mara arbid doe .i. clod $h$ ut dicitur mecon tua arabeth acladhaibh. (13va, 1. 30-32)

A STRONG LIGHT OVER THE SEA's RAMPART Over the rampart etc, [...] or, great is the light of Failbe over the rampart, i.e. over the dyke, or over the boundary of the sea, for there is a word doë meaning "rampart", as is said mecon tua ara-beth a cladhaibh "the great burdock which would be present on ramparts".

Lb: [...] (p. 84, 1. 12 IL)

\section{Coordinate Clauses}

Defining switched coordinate clauses is not entirely straightforward. It must be noted that, in this group, clauses are included that start with the abbreviated .i. for id est or ed ón "that is" and uel or nó »or«. These clauses are the very building blocks of commentary texts and are frequently used to compile information from different sources. As a result, these clauses have not always been included as code-switches in studies of historical bilingualism, since it is difficult to establish single authorship. ${ }^{60}$

60 Bisagni, Prolegomena, 26. 
As stated above, however, there are several reasons to include these glosses among the bilingual glosses of a particular manuscript. After all, these glosses were actively grouped together by a particular scribe and were read as such by their readers. In any case, establishing single authorship for any gloss in a commentary text is fraught with difficulties, since even glosses that do not contain markers of compilation may still have been influenced by it. These glosses have therefore been included here as switched clauses for F. Their inclusion, however, provides a good opportunity to examine whether these clauses are indeed particularly susceptible to the compilatory activities of scribes.

Of all the switched coordinate clauses (46), 15 start with .i., 6 start with $ł$ »or «, 21 start with 7 "and «, and 2 start with $\bar{s}$ »but«. Of the 5 examples that are not code-switches in Lb, 4 start with .i., which confirms that this particular connector can very easily be added onto other glosses or taken off of them in the course of transmission. This seems to have happened with at least three of the examples (\#2401b, \#0404a, \#2804a), illustrated here by the first:

\#2401b BABILl BRUTH OIR ORLÁIN .i. babillus epscop $7^{\text {martir inantoig i. inantiochia }}$ cum suis tribus filíís. (fol. 7va, l. 8-10)

BABYLAS, THE ABUNDANT MASS OF GOLD i.e. Babillus and [he was] a martyr [and] bishop in Antioch, i.e. in Antiochia with his three sons.

Lb: .i. babillus espoc inantoig cum suis tribus filis. (p. 80, 1. 16 LM-IL)

In $\mathrm{F}$, the name Babill is glossed with a string of elements that can be considered diamorphic (a personal name Babillus, the borrowing martir, an ambiguous abbreviation for the word »bishop", and a shared preposition in), followed by the Irish version of the name Antioch. This string of elements, in turn, is followed by a Latin gloss on the same subject. Lb, however, shares the first part of the gloss with F (Babillus espoc inantoig) but continues with the Latin prepositional phrase that is part of a separate gloss in F. Note, however, that the Latin element in F .i. inantiochia is inserted over the line and is likely to have been a later addition, either by the scribe of F or by the scribe of its exemplar(s). While the code-switch in Lb appears to be syntactically more complex than that in F, since it contains an inserted Irish prepositional phrase following a visual diamorph (the abbreviation eps), the two glosses are, in fact, very similar to each other if the Latin phrase is considered to be a later addition.

The two other examples in this category seem to be the result of, respectively, a deletion and a translation. In \#0406d, for example, both manuscripts have the same Irish glossing material, but only F also contains a Latin phrase:

\#0406d LA TARMrith Martíni .i. abreith inepiscopatum .i. ataisi aloc hiloc .i. athaisi tucta asin mainistir inerbail docum nacathrach moire non statim .i. abreth inepiscopatum $\nmid$ translatio corpore eius desepulcro inalium locum (fol. 21ra, 1. 5-8)

At the tRANSLATION of Martinus i.e. bringing him into the bishopric, i.e. his relics from place to place, i.e. his relics were brought from the monastery in which he died towards the great city and it was not immediately, i.e. bringing him into the bishopric or the translation of his body from the grave into another place.

Lb: .i. abreith inepiscopatum .i. athaissi [sic] alloc hilloc .i. tuctha athaissi asinmainistir inerbail dochum nacathrach (p. 89, $1.8 \mathrm{IL})$ 
In \#0605a, the code-switch in F occurs between two clauses that convey the same information, only one of them does so through Latin and the other through Irish:

\#0605 $\mathrm{a}^{61}$ hic cadit euasio íncolomis sancti iohannis apostoli ךeuangeliste. adímperium cesaris domicianí indolium feruentis olei missi ante portam latinam apud romam. .i. annso tig ternam eoin apstail ondabaig ola arfiuchad inarcuired é saroim ante portam latinam ar forcongra domincíani. (fol. 17vb, l. 1-9)

Here happened the unharmed escape of Saint John the apostle and evangelist who, at the command of Caesar Domitian, was thrown into a vat of boiling oil before the Porta Latina near Rome, i.e. here comes the escape of the apostle John from the tub of boiling oil into which he was cast in Rome before the Porta Latina by Domitian's order.

Lb: .i. sancti iohannis apostoli ante $e^{62}$ abimperio cesari .7dormtiano inferuentis oleíi doleum misus est 7 incolonis euassit. (p. 87, 1. 11 IL)

It is striking that Lb only has the Latin gloss on Saint John, which is slightly different from the Latin material in $\mathrm{F}$ in that it is shorter and also contains several errors. ${ }^{63} \mathrm{~F}$, on the other hand, preserves two accounts of this information, the second of which is mainly Irish and is probably a translation of the Latin, though not a word-for-word translation, as the order in which the information is given is slightly different.

\section{Long Alternations}

As to the long alternations, there is only one example that has changed significantly in terms of its code-switching behaviour:

\#1704e Donnan Ega UAIRE Sanctus donnanus ineglesia insula cumsua familia .i. l. duobus apiratis interfectus est Donnan egha dano ainm oilein fil inalbain 7isan $n$ sidhe ata donnan .i. icataibh ךibi donnan sanctus cum familia obiit .i. lii. ł lan ISe andonnansa docoidh foramus coluim .cille. diagabail danmcharait Condebairt colum .cille. fris nibam anmchara olse dolucht dercmartra uair raghaisiu indercmartra 7 domuinter lat 7 issed on rocomailled. Teid iarum conamuintir ingallghaidelaibh 7 geibid aitreb an $n$ baile ambitis cairigh rigna intire INnister don righain sin. Amarbad uile olsi. Nicreitmech sin olcach. Teacar cuca iarum dia marbad. IS and sin bui íncleiriuch ocanaiffriunn. Leicidh cairde dun cotair íntaiffrend oldonnan leicfider olsiat. Marbtar iarum iarsin ínlín badar uile. (fol. 15vb, 1. 28 - fol. [15a]r)

DonNáN OF CHILly EIg Saint Donnán [was] in a church on an island with his familia, i.e. Donnán was killed by pirates with 52 [others]. Ega is the name of an island which is in Scotland, and there Donnán is, i.e. in Caithness. And there Saint Donnán died with his familia, i.e. 52, or the full [number]

61 This gloss does not refer to a particular lemma in the martyrology but rather adds another event to be commemorated on the sixth of May.

62 Probably a corruption of the abbreviation for euangeliste.

63 Take for example the word ante discussed in the footnote above, which is likely to be a corruption of euangeliste, as well as the reading dormtiano for Domitiani. 
It is this Donnán that went to visit Colum Cille to get him as a soulfriend. And Colum Cille said to him, "I will not be a soulfriend, « he said, "to folk of red martyrdom for you will suffer red martyrdom and your family with you, " and this was fulfilled. Thereafter Donnán came with his family into (the country of the) Gallgaedil and settled there where the sheep of the queen of the country used to be. This is told to that queen. "Kill them all" said she. "That is not pious, " said everyone. Then people come to kill them. The cleric was then at mass. "Give truce to us till the mass ends, " said Donnán. "It shall be given, " said they, and thereafter all that were there were killed. (Adapted from Stokes, On the Calendar of Oengus, lxxiv-lxxv)

Lb: Lafeil petair deochain $7 \mathrm{r}$ Dondan ega .i. ega ainm oilein fil inalpain 7 isan $n$ side ata donnan $ł$ icattaib ךibi donnan sanctus cum sua familia obiit .i. .lun. Is he indondansa dochoid foramus choluim cille diagabail danmcharait. condebairt colum cille friss. nibamanmcharusa ol se dolucht dergmartra. uair ragusa indergmartra 7 domúinter lat. 7issed on rocomailled. Teit iarum donnan conamuinntir ingallgædelaib 7 gebid aittreb ind bail ambitis cærig rígna intíre. indister sin don rigain. Amarbad uile olsise. nicreitmech sin olcách. Tecar chuca iarum diamarbad. ISand sin bui inclerech ocaoifrend. Lécid cairde dun cotair inoifrend oldonnan. lécfider olsiat ocus marbthar iarum iarsin inlín batar uile. (p. 86, 1. 2 RM)

This gloss in F starts with a Latin main clause and coordinate clause, which, in turn, is followed by an Irish main clause. In Lb, however, this Irish main clause is the start of the gloss. It seems likely, therefore, that $\mathrm{F}$ or its precursor was again combining material from different sources and putting it together as one gloss, thereby creating a code-switch. Alternatively, Lb has omitted Latin material that was present in its exemplar, in which case we would be dealing with a deletion of Latin material.

\section{Shape-Shifting Code-Switches}

The previous examples all dealt with code-switches that appeared or disappeared during the transmission of the text. However, code-switches may not just appear or disappear. In the course of transmission, they may also be changed into a different type of code-switch. In this category, there are two patterns that have come to the fore: first of all, formulaic language and conventionalised code-switching seem to lend themselves to a certain degree of flexibility. For instance, in switched verb phrases and subordinate clauses used to introduce direct speech, different verbs or verbal inflections may occur:

\begin{tabular}{lll}
\hline $\mathrm{F}$ & $\mathrm{Lb}$ \\
\hline \#0102e & $\begin{array}{l}\text { Bercan dixit (fol. 8va, 1. 11) } \\
\text { \#0602a }\end{array}$ & $\begin{array}{l}\text { Berchan cecinit (p. 82, 1. 26 RM - BM) } \\
\text { ut dixit [poeta] (p. 81, BM) }\end{array}$ \\
\#0602a & ut dictum est (fol. 9rb, 1. 1) & \\
\#0503c & Patraig cecinit (fol. 11vb, l. 35) & ut dixit [poeta] (p. 81, BM) \\
\#3103a & ut dicitur (fol. 14va, l. 7) & ut dixit [poeta] (p. 84, l. 31 BM) \\
\hline
\end{tabular}


Unlike the examples of the subordinate clauses that appear in F but not in Lb, these phrases appear in matching positions in both manuscripts, but they use different verbs (dicere »to say" or canere "to sing") or different forms of the same verb (ut dictum est "as it is said" vs. ut dixit "as he said«). Perhaps, the fact that these phrases are highly abbreviated and function almost as emblematic diamorphs invites them to be realised in new copies according to a variety of conventionalised phrases essentially occurring in free distribution. ${ }^{64}$

Secondly, there seems to be a tendency in Lb to disambiguate abbreviations, especially in the case of the Tironian note 7 " and «. So far, I have come across five examples of this. ${ }^{65}$ Take, for example, this gloss on 21st February, in which the switched phrase starts with 7 in F, but with et (fully written out) in Lb:

\#0103a DaUID Cille Múine .i. dauid (GAP)ine dobretnaib deiscirt ב_arceepiscopus britaníe insole (fol. 11va, 1. 8-10)

David of Cell Muini i.e. David of Cell Muine of the Britons of the South, and [he was] archbishop of the island of Britain. (Adapted from Stokes 1880: lx)

Lb: Dauid chille muine dobretnaib descirt et archepiscopus britaniæ insolæ (p. 83, 1. 2 $\mathrm{RM}$ )

The following example includes not only the disambiguation of an abbreviation, but also a translation of the preceding switched prepositional phrase: ${ }^{66}$

\#1002c CRONAN CAIDH CENDIGNA ł comadh é mochua miliuca .i. cronan mac meallain oglais moir andeisib muman 7 didiu ata alis mor ł glais mor ceall robui itæbh shuird aness cotangadar goill dano inbir do $m$ an $n$ cuice coromarbsat amuin $n$ ter $\underline{\text { inuna nocte }}$ znullus defamilia eius euasit. (fols. 9va, l. $36-9 \mathrm{vb}, 1.5$ )

64 Stam, Typology of Code-switching, 332-338. For another example, see Clarke, Lore of the monstrous races, 33 n. 68.

65 More may be found, however, once a new transcription of Lb is completed. The 1880 edition cannot be trusted in this regard, as the editor sometimes disambiguated abbreviations.

66 An example of disambiguation into Irish:

\#1605a Togairm Brenaind Cluana Togairm brenaind 7rł. [...] Uair adberat cenel fiachach gurub of hiachach mac neill .ix.giallaig atat fessin 7niheth ader anrannsa acht ofhiachaig mac maile breissi 7 necio postea 7íníc intsharaighti sin $\mathrm{t} u c \mathrm{~d} h \mathrm{hos}$ corr do .h. shuanaigh $7 \mathrm{t} u \mathrm{cad} h$ nadaine doronsat inecht .i. h. gilla suanaigh hiraithin. (fols. 18vb, l. 34 - 19ra, l. 2)

THE CALLING OF BRENANN OF CLÚAIN The calling of Brenann etc. [...] For the race of Fiacha say that they themselves come from Fiacha son of Niall the Nine Hostages, and this is not so, as this quatrain says, but (they come) from Fiacha son of Maelbressi, and I do not know it after this and, in compensation for that outrage, Ross Corr was given to Hua Suanaig and the men who committed the crime were (also) given, i.e. the descendants of Gille Suanaig in Rathin. (Adapted from Stokes, On the Calendar of Oengus, lxxxvii)

Lb: uair atberait cenel fiachach corubofiachu mac neill. ix.giallaig attatt fessin. ocus nihed amal atbeir inrannsa|\ $\|$ acht ofiachu mac moilebressi בnescio postea. ocus inhicc intsáraigthesin tucad ross corr do .h. suanaig 7 tucad nadaine doronsat inecht beos .i. h. gille shuanaig iraithin., (p. 90 BM) 
Cronán the Chaste, without Reproach Or he may be Mochua Miliuca, i.e. Cronan son of Mellan from Glais Mór in the Deise of Munster, and it is then in Lismore, or from Glais Mór, a church that was on the southern side of Swords and the foreigners of Inver Domnann came there and slew his family in one night and none of his familia escaped. (Adapted from Stokes, On the Calendar of Oengus, l)

Lb: .i. sinand. $\nmid$ isna dessib .i. ceall fas prisordanes .i. cronan mac mellan oglais moir indessib muman 7 didiu ata illiss mor. $\nmid$ glais mor. ceall robui itoeb suird alla aness cotancutar gaill indbir domnand chuice cormarbsat amunntir inoenaidche et nullus de famamilia [sic] eius euasit. (p. 81, 1. 20 IL RM)

Whereas this switch in F might have been classified as a long alternational switch - starting with a prepositional phrase and continuing into a main clause - the switch in Lb is confined to the main clause and therefore shows a greater segregation of the two languages. Instances such as these may also indicate how this particular scribe read the visual diamorphs or how they thought they should be read.

\section{Conclusions}

The aim of this case study has been to discern in what way scribes dealt with the bilingual material they encountered in the Commentary to the Félire Oengusso. While the sample size is still small, several patterns seem to emerge already at this stage. First of all, we may note the stability of code-switching in the transmission of these two manuscripts. On average, $72 \%$ of the code-switches that occur in $\mathrm{F}$ also occur in $\mathrm{Lb}$, with a much higher percentage within some of the linguistic categories involved. While these switches may have been the result of the mobility and merger of material inherited from earlier stages of the transmission of this text, the fact that they are so consistently retained demonstrates that they maintained their relevance as a mode of communication for at least these two fifteenth-century scribes and the audience they had in mind.

Secondly, the hypothesis that the grammatical characteristics of a gloss may influence its transmission is partially confirmed: the transmission of these switches does not seem to depend solely on their complexity or simplicity, but more so on their grammatical embeddedness in the sentence or on a combination of the two factors. For example, simple switches with strong grammatical ties, like determiner phrases and noun phrases, occur more frequently in both manuscripts than simple switches with loose grammatical ties, like adverbial phrases or prepositional phrases. A similar process seems to apply to the longer, more complex switches that stretch across phrases and clauses: these are more likely to occur in both manuscripts than main clauses, probably because they are tied to the preceding material more strongly. The grammatical integration of a code-switch and its complexity may therefore act as predictors for its chances of being transmitted faithfully.

When zooming in on the reasons for the lack of transmission, we see that different grammatical switch categories present different arrays of causes. Material that has only loose grammatical ties to its textual context, such as adverbial phrases, main clauses, subordinate clauses, and coordinate clauses, has a greater mobility in transmission and is more likely to occur as separate monolingual glosses. In the case of the subordinate clauses discussed here, many of these are formulaic in nature as well, and may be employed as "textual glue", gluing together in one manuscript material that is presented as separate sections in another. Switches that have stronger grammatical ties to their textual surroundings, like noun phrases or determiner phrases, are more likely to be translated or deleted. 
Thirdly, it seems that there is a greater flexibility in the transmission of code-switches that are either highly abbreviated or conventionalised. This perhaps accounts for the fact that many adverbial phrases are frequently translated or deleted, despite their loose grammatical ties, as many of them seem to function as visual diamorphs. For highly abbreviated code-switches, this is as expected, since these switches form part of the emblematic class of visual diamorphs that could be read in a variety of ways. For the conventionalised switches, however, this is unexpected as they could be considered simple switches that are more petrified than others. Perhaps, the flexibility in the transmission of these conventionalised switches points to the fact that these phrases, too, are emblematic in nature and may, after all, be classified as a specific sub-type of visual diamorph.

Lastly, visual diamorphs are occasionally disambiguated in Lb at switch points, both into Irish and into Latin. This, perhaps, may be the result of unconscious code-switches triggered by the ambiguous nature of the diamorphs themselves. However, if a stronger pattern emerges from a further analysis of the material, it may point to a greater preference on the part of the scribe to segregate the two languages more clearly.

The project will continue to examine whether these patterns persist and whether new patterns emerge. The comparison between the various copies of the Commentary to the Félire Oengusso will hopefully provide a window on scribal practice in a bilingual text, so that we may learn more about the scribes themselves, their interests, and their training, but also about the readers for whom they worked so hard.

\section{Acknowledgements}

This case study was carried out as part of an O'Donovan Scholarship (2018-2021) at the School of Celtic Studies, with which I aim to analyse the ways in which code-switches in the Commentary to the Félire Oengusso change during transmission. I am grateful to the School for giving me the opportunity to explore these topics, and I would like to acknowledge the support of Liam Breatnach whose advice has greatly improved this article. The article itself came out of the workshop "Understanding Medieval Multilingual Sermons", held at the Austrian Academy of Sciences in 2018, and I would like to thank Jan Odstrčilík for organising this inspiring event as well as Pavlina Rychterová and the anonymous reviewer of Medieval Worlds for their careful reading of the text and their insightful comments on the draft. 


\section{References}

\section{Manuscripts}

B = Cambridge, Trinity College, MS B.10.5.

B1 = Brussels, Koninklijke Bibliotheek Brussel, 5100-4.

B2 = Brussels, Koninklijke Bibliotheek Brussel, 5057-5059.

$\mathrm{C}=$ Dublin, National Library of Ireland, G10.

F = Dublin, University College Dublin, Franciscan A7

$\mathrm{L}=$ Oxford, Bodleian Library, Laud 610.

Lb = Dublin, Royal Irish Academy 23 P 16.

$\mathrm{P}=$ Dublin, Royal Irish Academy $23 \mathrm{P} 3$.

R1 = Oxford, Bodleian, Rawl. B505.

R2 = Oxford, Bodleian, Rawl. B512.

$\mathrm{Wb}=$ Würzburg, Universitätsbibliothek, MS M.p.th.f.12.

Bériou, Nicole, Orality in its written traces: bilingual Reportationes of sermons in France (thirteenth Century), Medieval Worlds 12 (2020) 169-184, DOI: 10.1553/medievalworlds_no12_ 2020 s169.

Bisagni, Jacopo, Prolegomena to the study of code-switching in the Old Irish Glosses, Peritia 24-25 (2013-2014) 1-58.

Bisagni, Jacopo, Amrae Coluimb Chille: a Critical Edition (Dublin, 2019).

Blom, Alderik, Glossing the Psalms: The Emergence of the Written Vernaculars in Western Europe from the Seventh to the Twelfth Centuries (Berlin, 2017).

Brown, Keith, and Jim Miller, The Cambridge Dictionary of Linguistics (Cambridge, 2013).

Breatnach, Liam, Poets and poetry, in: Kim McCone and Katharine Simms (eds.), Progress in Medieval Irish Studies (Maynooth, 1996) 65-77.

Charles-Edwards, Thomas, The manuscript transmission of Bretha Comaithchesa, in: Elizabeth Boyle and Deborah Hayden (eds), Authorities and Adaptations: The Reworking and Transmission of Textual Sources in Medieval Ireland (Dublin, 2014) 95-120.

Clarke, Michael, The lore of the monstrous races in the developing text of the Irish Sex Aetates Mundi, Cambrian Medieval Celtic Studies 63 (2012) 15-50.

Clyne, Michael, Dynamics of Language Contact: English and Immigrant Languages (Cambridge, 2003).

Delcorno, Carlo, Bilingualism in medieval Italian preaching: the case of Angelo Da Porta Sole (d. 1334), Medieval Worlds 12 (2020) 185-209, DOI: 10.1553/medievalworlds_ no12_2020s185.

Dijkstra, Ton, Ellen De Bruijn, Herbert Schriefers, and Sjoerd Ten Brinke, More on interlingual homograph recognition: language intermixing versus explicitness of instruction, Bilingualism: Language and Cognition 3/1 (2000) 69-78.

Dillon, Myles, Canice Mooney and Pádraig de Brún, Catalogue of Irish Manuscripts in the Franciscan Library, Killiney (Dublin, 1969).

Dumville, David, Latin and Irish in the Annals of Ulster, A.D. 431-1050, in: David Dumville (ed.), Histories and Pseudo-Histories of the Insular Middle Ages (Aldershot, 1990) 320-341.

Dumville, David, Félire Óngusso. Problems of dating a monument of Old Irish, Éigse 33 (2002) 19-48. 
Grosjean, François, Studying bilinguals: methodological and conceptual Issues, Bilingualism: Language and Cognition 1 (1998) 131-149.

Grosjean, François, Bilingual and monolingual language modes, in: Carol A. Chapelle (ed.), The Encyclopedia of Applied Linguistics (Hoboken, NJ, 2013).

Hennessy, William M. and Bartholomew Mac Carthy, Annala Uladh: Annals of Ulster otherwise Annala Senait, Annals of Senat: a chronicle of Irish affairs from A.D. 431 to A.D. 1540. 4 vols. (Dublin, 1887-1901; repr. Dublin, 1998). Accessed on 12 April 2021: celt.ucc. ie/published/G100001C.html.

Hennig, John, Studies in the Latin texts of the Martyrology of Tallaght, of Félire Oengusso and of Félire Húi Gormáin, Proceedings of the Royal Irish Academy, 69 C (1970) 45-112.

Moran, Pádraic, Language interaction in the St Gall Priscian Glosses, Peritia 26 (2015) 113-142.

Murphy, Gerard, Early Irish Metrics (Dublin, 1961).

Muysken, Pieter, Bilingual Speech: A Typology of Code-Mixing (Cambridge, 2000).

Myslín, Mark, and Roger Levy, Code-switching and predictability of meaning in discourse Language 91/4 (2015) 871-905.

Negoi, Lidia, Bilingual strategies in fourteenth-century Latin sermons from Catalonia, Medieval Worlds 12 (2020) 210-233, DOI: 10.1553/medievalworlds_no12_2020s210.

Ní Shéaghdha, Nessa, Catalogue of Irish Manuscripts in the National Library of Ireland, 13 vols (Dublin, 1967).

Ó Concheanainn, Tomás, The scribe of the Leabhar Breac, Ériu 24 (1973) 64-79.

Ó Corráin, Donnchadh, What happened Ireland's medieval manuscripts?, Peritia 22-23 (2011-2012) 191-223.

Ó Cuív, Brian, Catalogue of Irish Manuscripts in the Bodleian Library at Oxford and Oxford College Libraries (Dublin, 2001).

O'Donovan, John, James Henthorn Todd and William Reeves, The Martyrology of Donegal. (Dublin, 1864). Accessed on 12 April 2021: archive.org/details/ martyrologydoneooreevgoog/page/n3.

Odstrčilík, Jan, Multilingual medieval sermons: sources, theories and methods, Medieval Worlds 12 (2020) 140-47, DOI 10.1553/medievalworlds_no12_2020s140.

Ó Flaithearta, Mícheál and Lars Nooij (eds.), Code-Switching in Medieval Ireland and England: Proceedings of a Workshop on Code-Switching in the Medieval Classroom, Utrecht 29th May, 2015 (Bremen, 2018).

Ó Riain, Pádraig, Feastdays of the Saints: A History of Irish Martyrologies (Brussels, 2006).

Pahta, Päivi, Janne Skaffari and Laura Wright (eds.), Multilingual Practices in Language History: New Perspectives (Berlin, 2018).

Russell, Paul, Irish language, in: John T. Koch (ed.), Celtic Culture: A Historical Encylopedia. 5 vols (Oxford, 2006).

Schendl, Herbert, Multilingual texts as a reflection of code-switching in medieval England: sermons and beyond, Medieval Worlds 12 (2020) 148-168, DOI: 10.1553/medievalworlds _ no12_2020s148.

Schendl, Herbert and Laura Wright (eds.), Code-Switching in Early English (Berlin, 2011).

Sebba, Mark, Shahrzad Mahootian and Carla Jonsson (eds.), Language Mixing and Code-Switching in Writing: Approaches to Mixed-Language Written Discourse (New York, 2012).

Sharpe, Richard, Books from Ireland, fifth to ninth centuries, Peritia 21 (2010) 1-55. 
Stam, Nike, A Typology of Code-switching in the Félire Oengusso (Utrecht, 2017). OA download available at: www.lotpublications.nl/a-typology-of-code-switching-in-the-commentary-to-the-f\% $\mathrm{C} 3 \%$ A9lire-\% $3 \%$ B3engusso.

Stokes, Whitley, On the Calendar of Oengus, The Transactions of the Royal Irish Academy: Irish Manuscript Series 1 (1880) 1-352.

Stokes, Whitley, Félire Oengusso Céli Dé: The Martyrology of Oengus the Culdee (London, 1905).

Strachan, John, Contributions to the history of the deponent verb in Irish, Transactions of the Philological Society 22 (1894) 444-568.

Ter Horst, Tom, Typology and spectrum of Latin-Irish and Latin-English code-switches in medieval sermon literature, Medieval Worlds 12 (2020) 234-54, DOI: 10.1553/medievalworlds_no12_2020s234.

Ter Horst, Tom, Codeswitching in the Irish-Latin Leabhar Breac: Mediaeval Homiletic Culture (Utrecht, 2017). OA download at: www.lotpublications.nl/codeswitching-in-theirish-latin-leabhar-breac.

Ter Horst, Tom, and Nike Stam, Visual Diamorphs: The importance of language neutrality in code-switching from medieval Ireland, in: Päivi Pahta, Janne Skaffari and Laura Wright (eds.), Multilingual Practices in Language History: New Perspectives (Berlin, 2018) 223-242.

Thurneysen, Rudolf, Die Abfassung des Félire von Oengus, Zeitschrift für celtische Philologie 6 (1907) 6-8.

Thurneysen, Rudolf, A Grammar of Old Irish (Dublin, 1946; repr. 2003).

Voigts, Linda Ehrsam, The character of the carecter: ambiguous sigils in scientific and medical texts, in: Alastair J. Minnis (ed.), Latin and Vernacular: Studies in Late-Medieval Texts and Manuscripts (York, 1989) 91-109.

Wright, Laura, On variation in medieval mixed-language business writing, in: Laura Wright and Herbert Schendl (eds.), Code-Switching in Early English (Berlin, 2011) 191-218.

\section{Websites}

CELT: The Online Resource for Irish History, Literature and Politics. Annals of Ulster; Digitised from Hennessy, William M., and B. Mac Carthy (1887-1901)), Annala Uladh: Annals of Ulster, otherwise Annala Senait, Annals of Senat: a chronicle of Irish affairs from A.D. 431 to A.D. 1540, 4 vols, 1st ed., Dublin, 1887-1901. Accessed on 3 April 2019: www.ucc. ie/celt.

CODECS. Collaborative Online Database and e-Resources for Celtic Studies. Accessed on 14 May 20201 www.vanhamel.nl/codecs.

Irish Script On Screen - Meamram Páipéar Ríomhaire. Accessed on 3 April 2019: www.isos. dias.ie.

A Dictionary of the Old-Irish Glosses in the Milan Codex. Accessed on 3 April 2019: www. univie.ac.at/indogermanistik/milan_glosses/.

\section{List of Figures}

Fig. 1: The 1911 stemma of (C)FÓ, Ó Riain, Feastdays, 177.

Fig. 2: Ó Riain's stemma for CFÓ, Ó Riain, Feastdays, 182. 